P-ISSN : 2715-744X

E-ISSN : 2721-916X

\title{
IDEOLOGI VIRUS DALAM REVIEW IDEOLOGI DAN FILSAFAT SOSIAL
}

\author{
Oleh: Sujarwa ${ }^{1}$ dan Endang Sri Handayani ${ }^{2}$
}

DOI:

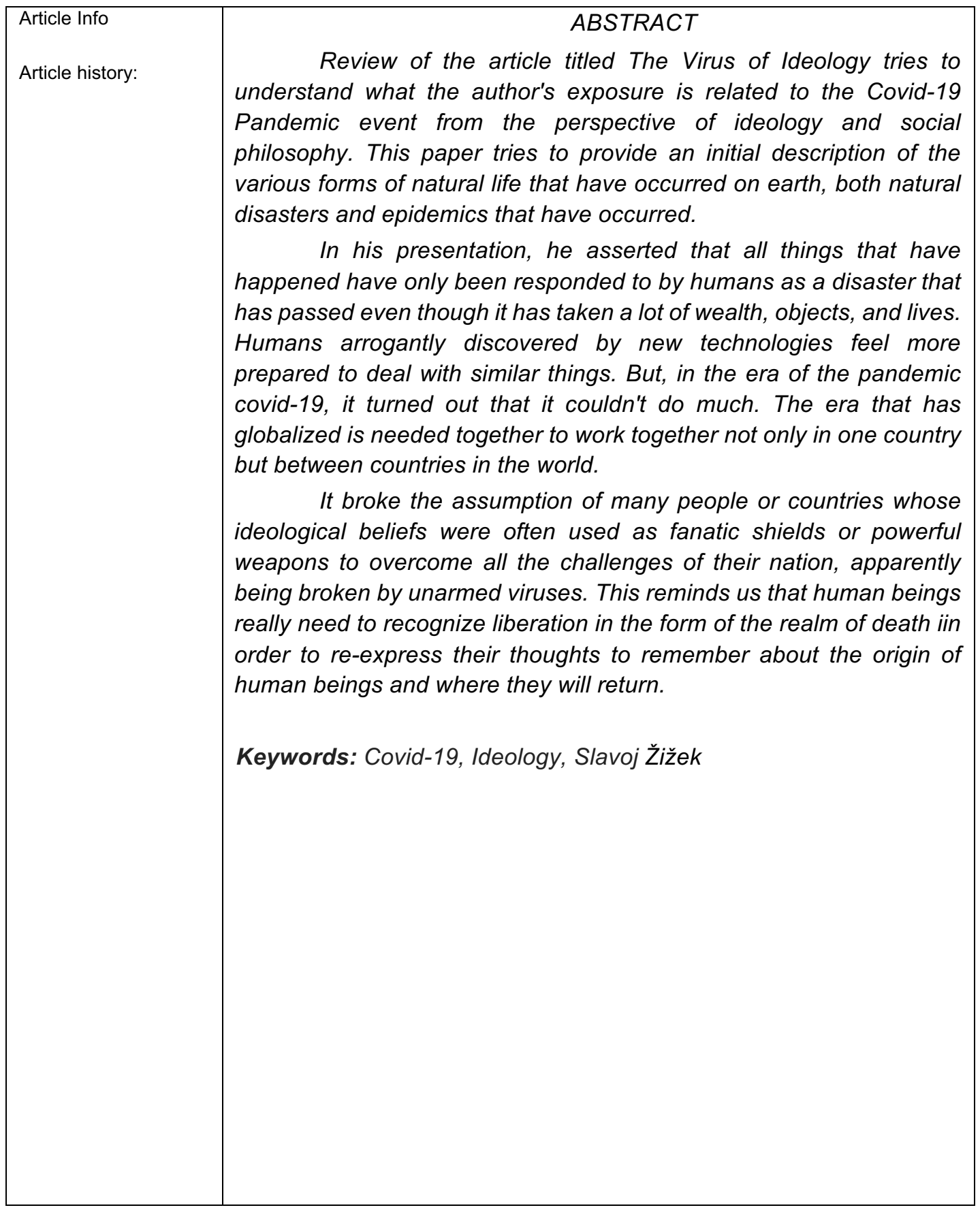

${ }^{1}$ Dosen Program Studi Sastra Indonesia, FSBK, Universitas Ahmad Dahlan Yogyakarta

${ }^{2}$ Dosen Program Studi Pendidikan Seni Rupa, FKIP, Universitas Sebelas Maret Surakarta 


\begin{tabular}{|c|c|}
\hline & ABSTRAK \\
Tulisan ini mengulas buku yang berjudul The Virus of Ideology \\
dengan mencoba memahami hubungan apa yang telah dipaparkan \\
penulis terkait peristiwa Pandemi Covid-19 dari perspektif ideologi dan \\
filsafat sosial. Tulisan ini mencoba memberikan deskripsi awal tentang \\
berbagai bentuk kehidupan alami yang telah terjadi di bumi, baik \\
bencana alam maupun epidemi yang telah terjadi. \\
Dalam presentasinya, ia menegaskan bahwa semua hal yang \\
terjadi hanya ditanggapi oleh manusia sebagai bencana yang telah \\
berlalu walaupun telah memakan banyak harta, benda, dan \\
kehidupan. Manusia yang sombong ditemukan oleh teknologi baru \\
merasa lebih siap untuk menghadapi hal serupa namuni di era \\
pandemi covid-19 ternyata semua tidak bisa berbuat banyak. Era yang \\
telah mengglobal dibutuhkan untuk bekerja bersama tidak hanya di \\
satu negara tetapi juga di antara negara-negara di dunia. \\
Hal ini mematahkan anggapan banyak orang atau negara \\
yang kepercayaan ideologisnya sering digunakan sebagai perisai \\
fanatik atau senjata ampuh untuk mengatasi semua tantangan bangsa \\
mereka, yang tampaknya dihancurkan oleh virus yang tidak \\
bersenjata. Ini mengingatkan kita bahwa manusia benar-benar perlu \\
mengenali pembebasan dalam bentuk dunia kematian untuk \\
mengekspresikan kembali pemikiran mereka untuk mengingat tentang \\
asal usul manusia dan ke mana mereka akan kembali. \\
Kata kunci : Covid-19, Ideologi, Slavoj Žižek
\end{tabular}

\section{PENDAHULUAN}

Tulisan ini mencoba untuk memaparkan apa yang pernah ditulis SLAVOJ ŽIŽEK terkait masalah pandemic covid-19 dalam bukunya yang berjudul

\section{PANDEMIC! COVID-19 Shakes the}

World. Paparan ini hanya mencoba untuk mengangkat salah satu contents dari buku tersebut yang berjudul The Virus of Ideology. Tulisan itu sebenarnya sudah agak lama karena buku itu ter- bit di awal pandemic kurang lebih tiga bulan yang lalu. Namun, bagi penulis sepertinya belumah usang karena sampai sekarang juga belum dipandang usai. 
Satu hal yang perlu disampaikan bahwa apa yang ditulis pengarang buku ini bukanlah masalah cara penanganan pandemic covid-19. Namun, memahami bagaimana sifat manusia pada umumnya suka mengingat namun untuk melupakan. Ia menjadikan peristiwa bersejarah, musibah, dan bencana sebatas diingat lalu untuk dilupakan, bukan untuk mereview diri apa yang terjadi pada peristiwa itu. Mereka tidak segera mengambil hikmah dari semua peristiwa yang ditimpakan sebagai ranah instropeksi diri bahwa kebenaran itu bukan pada hak manusia melainkan hak Illahi. Kebenaran yang disangkakan manusia cenderung subjektif, dan relative tetapi peristiwa alam maupun musibah di muka bumi adalah fakta nyata kehidupan bahwa manusialah pembawa bencana. Sebagaimana Al Qur'an telah mengabarkan bahwa setiap musibah dan kerusakan di muka bumi itu karena ulah manusianya. Meskipun hal itu adakalanya sebagai bentuk refres atas pikiran manusia yang suka mengingat namun cenderung untuk melupakan karena kepentingan ego sektoral. Musibah dan kematian sebagai bentuk refres atau model pembebasan alam pemikiran manusia atas keberadaannya di muka bumi agar tidak sebatas mengingat untuk melupakan. Untuk memahami hal itu berikut teks artikel The Virus of Ideology dalam versi terjemahan secara harafiah kami sampaikan.

\section{TEKS IDEOLOGI VIRUS (OLEH SLAVOJ ŽIŽEK)}

Satu pertanyaan menarik yang timbul ketika pandemi virus korona terjadi, bahkan untuk seseorang yang tidak ahli dalam bidang statistic seperti saya, ialah, di mana data berakhir dan ideology dimulai? Terdapat suatu paradoks yang timbul di sini: semakin banyak dunia kita saling terhubung, maka semakin banyak pula bencana lokal yang dapat memicu ketakutan secara global dan akhirnya menjadi sebuah bencana. Pada musim semi tahun 2010, awan debu yang berasal dari letusan kecil gunung berapi di Islandia, yang merupakan suatu gangguan kecil dalam mekanisme kompleks kehidupan di bumi, menghentikan lalu-lintas udara di sebagian Eropa. Hal tersebut merupakan pengingat yang tidak dapat diabaikan tentang bagaimana, terlepas dari semua aktivitasnya yang luar biasa dalam mengubah alam, umat manusia tetap hanyalah salah satu dari sekian banyak spesies yang hidup di planet bumi. Dampak sosial ekonomi yang sangat dahsyat dari ledakan kecil tersebut dikarenakan kerapuhan perkembangan teknologi kita, dalam hal ini perjalanan udara. Satu abad yang lalu, letusan seperti itu akan berlalu 
tanpa disadari. Perkembangan teknologi membuat kita lebih mandiri daripada alam dan pada saat yang sama, pada tingkat yang berbeda, lebih bergantung pada keinginan alam. Dan hal yang sama juga berlaku untuk penye- baran corona virus: jika saja hal tersebut terjadi sebelum reformasi Deng Xiaoping, kita mungkin bahkan tidak akan pernah mendengarnya.

Satu hal yang pasti: isolasi sendiri, membangun beberapa tembok baru dan selanjutnya karantina, tak akan menyelesaikan masalah tersebut. Dibutuhkan solidaritas yang tinggi dan respon global yang terkoordinasi, suatu bentuk baru dari yang dulu disebut sebagai komunisme. Jika kita tidak mengarahkan upaya kita arah ini, maka Wuhan hari ini mungkin menjadi kota khas yang ada di masa depan kita. Banyak dystopia yang sudah membayangkan hal yang serupa: kita tinggal di rumah, bekerja di computer kita, berkomunikasi melalui video konferensi, berolahraga menggunakan mesin yang terdapat di sudut rumah kantor kita, kadangkadang matsurbasi di depan layar yang menampilkan seks hardcore, dan mendapatkan makanan melalui pengiriman, tidak pernah melihat manusia secara langsung.

Namun, terdapat prospek emansipatoris yang tak terduga yang tesembunyi dalam visi mimpi buruk ini. Saya harus mengakui bahwa akhir-akhir ini saya mendapati diri saya bermimpi mengunjungi Wuhan. Jalan-jalan yang ditinggalkan di kota megalopolis pusat-pusat kota yang biasanya ramai sekarang seperti kota hantu, toko-toko dengan pintu terbuka akan tetapi tidak ada pelanggan yang datang, hanya pejalan kaki seorang diri maupun mobil tunggal di sanasini, hal tersebut memberikan gambaran sekilas seperti apa dunia non-konsumeris akan terlihat. Keindahan melankolis dari jalanan yang kosong di Shanghai atau Hong Kong mengingatkanku pada beberapa film lama pasca-apokaliptik seperti On the Beach, yang memperlihatkan sebuah kota dengan sebagian besar penduduknya dihancurkan/ dibinasakan tidak ada penghancuran besar, hanya saja dunia di luar sana yang sudah tidak lagi siap sedia, menunggu kita, menatap kita, dan untuk kita. Bahkan topeng putih yang dikenakan oleh beberapa orang yang berjalan di area sekitar memberikan kesan anonimitas dan kebebasan dari tekanan sosial terhadap sebuah pengakuan.

Banyak dari kita yang mengingat kesimpulan terkenal dari manifesto situasional siswa yang diterbitkan pada tahun 1966: Vivre sans temps mort, joir sans 
entraves (hidup tanpa waktu kematian, menikmati tanpa hambatan). Jika Freud dan Lacan mengajari kita sesuatu, maka rumus inilah, kasus tertinggi dari keputusan superego (karena, seperti yang ditunjukkan oleh Lacan secara tepat, superego pada dasarnya merupakan keputusan positif untuk dinikmati, bukan tindakan negative untuk melarang sesuatu) hal tersebut sebenarnya adalah resep untuk suatu bencana: dorongan untuk mengisi setiap saat dari waktu yang diberikan kepada kita dengan keterlibatan yang intens tak terhindarkan kemudian berakhir dengan kemonotonan yang menyesakkan. Waktu kematian merupakan saat-saat untuk mengundurkan diri, dari apa yang disebut oleh mistikus lama Gelassenheit, pelepasan adalah sesuatu hal yang sangat penting untuk merevitalisasi pengalaman hidup kita. Dan, mungkin, orang dapat berharap bahwa salah satu konsekuensi yang tidak diinginkan dari karantina corona virus di kota-kota di seluruh dunia adalah bahwa beberapa orang setidaknya akan menggunakan waktu mereka yang berasal dari aktivitas yang sibuk dan (tidak) memikirkan rasa kesulitan mereka.

Saya sepenuhnya sadar akan bahaya yang ingin saya capai dalam mempublikasikan pemikiran-pemikiran ini.
Apakah saya tidak akan terlibat dalam versi baru yang dikaitkan dengan korban penderitaan dari beberapa wawasan otentik yang lebih dalam dari posisi eksternal saya yang aman dan dengan demikian secara sinis melegitimasi penderitaan mereka? Ketika seorang penduduk Wuhan yang mengenakan masker berkeliling mencari obat-obatan atau makanan, pasti tidak ada pemikiran antikonsumeris di benaknya, hanya ada rasa panik, marah, dan takut. Permohonan saya hanyalah bahwa peristiwa mengerikan dapat memiliki konsekuensi positif yang tidak terduga.

Carlo Ginzburg mengusulkan gagasan bahwa merasa malu terhadap negara seseorang, bukan menyukainya, mungkin merupakan tanda yang sebenarnya dari menjadi milik negara tersebut. Mungkin, dalam masa isolasi dan keheningan yang dipaksakan ini, beberapa orang Israel akan mengumpulkan keberanian untuk merasa malu dalam kaitannya dengan politik yang dilakukan atas nama mereka oleh Netanyahu dan Trump tentu saja tidak, dalam hal rasa malu karena menjadi Yahudi tetapi, pada sebaliknya, merasa malu atas apa yang dilakukan politik Israel di West Bank terhadap warisanYudaisme yang paling berharga itu. Mungkin, beberapa orang 
Inggris akan mengumpulkan keberanian untuk merasa malu karena jatuh cinta pada mimpi ideologis yang membawa mereka pada Brexit. Akan tetapi, untuk orang-orang yang melakukan isolasi di Wuhan dan di seluruh dunia, ini bukan saatnya untuk merasa malu dan terstigmatisasi melainkan waktu untuk mengumpulkan keberanian dan dengan sabar bertahan dalam perjuangan mereka. Satusatunya yang merasa malu di China adalah mereka yang secara terbuka meremeh- kan pandemic sambil melindungi diri mereka sendiri, bertindak seperti para pejabat Soviet di sekitar Chernobyl yang secara terbuka menyatakan tidak ada bahaya saat segera mengevakuasi keluarga mereka sendiri, atau para manajer tingkat tinggi yang secara terbuka menyangkal pema- nasan global tetapi sudah membeli rumah di Selandia Baru atau membangun bunker untuk ber- tahan hidup di Pegunungan Rocky. Mungkin kemarahan public terhadap standard ganda seperti itu (yang sudah memaksa pihak berwenang untuk menjanjikan transparansi) akan melahirkan efek samping positif yang tidak diinginkan dari krisis ini.

\section{REVIEW ATAS TEKS (IDEOLOGI VIRUS)}

Tulisan pada PANDEMIC! Covid-19 bab 6 tentang Ideologi Virus tersebut menarik, karena penulis mencoba membandingkan alam pikiran manusia yang 'amat cinta idologi' dengan kasus 'pandemi virus corona'. Dalam pandangan penulis orang yang sangat cinta ideology sampai amat sangat fanatik, segala tindakan dan alam pikirannya akan selalu diorientasikan dan diukur dengan 'brand' ideologinya, sehingga adakalanya lengah justru tidak terkontrol tindakannya melampaui batas ideology itu sendiri. Ia bisa bertindak dan berpikir menurut kepentingannya, melampaui batas ideologinya. Bagaimana ketika terjadi khasus 'pandemi virus corona' yang semula banyak tokoh dunia hanya memandang sepele menimpa satu negara dengan ideology yang berbeda.

Banyak tokoh pemimpin dunia menyepelekan karena berada di wilayah negara berbeda dan ideologi yang berbeda pula. Mereka berpandangan itu urusan mereka karena ediologi yang berbeda. Namun, Allah atau Tuhan (bagi yang berkeyakinan adanya Tuhan) ternyata berkehendak lain, sekarang dunia dihadapkan pada hal yang sama yaitu mengatasi kasus 'pandemi virus corona' yang menyebar ke seluruh wilayah dunia. Negara-negara di dunia tidak lagi ribut dan bangga dengan 
ideologinya, mereka berusaha keras untuk melawan virus corona, butuh kebersamaan. Kemajuan teknologi yang selama ini diagungkan tidak dapat berbuat banyak, semua orang ketakutan pada virus yang mematikan itu meski virus itu tak bermerek ediologi. Ternyata manusia tidak mampu melakukan 'pembebasan diri' sebatas dengan 'kenikmatan hidup' dengan terpenuhinya semua kebutuhan dan keinginan lalu merasa terbebas dari kesulitan, penyakit, dan kematian, meski sudah berdalih dengan keyakinan ideologi negaranya yang ampuh, memiliki sejarah panjang kebesaran, kejayaan, dan dipuja seperti pusaka. Mereka semua takut menghadapi virus corona, takut kematian menjemput, mereka semua harus merefres dirinya untuk 'pembebasan diri' dari kematian dengan menempuh jalan sulit bukan dengan jalan kenikmatan.

Penulis juga menyadarkan kita semua untuk mengingat kembali pikiran Froud dan Lacan, sebagai ilmuwan psikologi, yang pernah melontarkan konsep 'pembebasan' bagi manusia masa lalu yang mengindahkan keyakinan sebagai manusia bertuhan. Dengan bertuhan mereka percaya akan kematian sebagai bentuk 'pembebasan diri' dari segala kesulitan. Dengan kata lain, kematian cepat atau lambat akan terjadi pada setiap makhluk
Tuhan, termasuk manusia, semua itu sebagai bagian dari pembebasan diri atas segala kesulitan hidup.

Berbeda halnya dengan khasus pandemic virus corona, meraka semula menganggap sebagai masalah satu negara dengan sudut pandang ediologinya yang berbeda. Masing-masing negara yang telah berteknologi maju menganggap dengan teknologinya yang lebih maju mampu menangkal virus tersebut dengan jumawa. Kesadaran bahwa alam semesta raya itu adalah satu dalam globalitas terlupakan oleh negara-negara di dunia, ketika ada gejala wabah virus corona hanya dipahami sebagai ideology yang berbeda. Ternyata wabah itu bukan milik satu negara, bangsa, dan bahkan ideology melainkan sebagai khasus global yang tidak bisa ditangani satu negara, satu bangsa, melainkan dibutuhkan sinergi yang saling membantu untuk bekerjasama dari aspek manapun. Dengan kata lain, keberadaan virus corona mampu mengalahkan pandangan ideology mereka yang berbeda untuk bersama-sama melawan virus corona, agar terhindar dari kematian.

Intinya buku ini mengkritisi alam pikiran manusia yang tidak malu-malu suka menggunakan standart ganda untuk mencapai tujuan dan kepentingannya sendiri, maka 
disadarkan dengan sebuah perbandingan: ideology ibarat virus dalam diri manusia, yang sering kali terlalu sombong dengan keahliannya dan lupa bahwa pada dasarnya manusia itu ada yang menciptakannya. Hal itu dalam filsafat Jawa disebut sangkan paraning dumadi (dari mana manusia itu ada dan kemana manusia itu akan kembali). Sudah saatnya manusia itu untuk berintropeksi diri bahwa di balik kesuksesan manusia itu ada relasi horizontal dan vertical, yang bisa membawa jalan terang dunia wal akhirat.

\section{DAFTAR PUSTAKA}

ŽIŽEK, $\quad$ SLAVOJ. 2020. PANDEMIC! COVID-19 Shakes the World, diambil dari Contents: The Virus of Ideology. Published by OR Books, New York and London.

Diterjemahkan dan Direview oleh:

1. Sujarwa, Dosen Prodi Sastra Indonesia, FSBK, UAD (Studi Program Doktor Kajian Budaya UNS).

2. Endang Sri Handayani, Dosen Prodi Pendidikan Seni Rupa, FKIP, UNS (Studi Program Doktor Kajian Budaya UNS). 